Doi: $10.4274 /$ vhd.36036

Viral Hepatitis Journal 2015; 21(1): 1-7

\title{
Hepatitis B Virus: Biology and Life Cycle
}

\author{
Hepatit B Virüsü: Biyolojisi ve Yașam Siklusu
}

\author{
Neşe INAN1, Fehmi TABAK2 \\ 1/stanbul Bilim University Faculty of Medicine, Department of Microbiology, Istanbul, Turkey \\ 2Istanbul University Cerrahpaşa Faculty of Medicine, Department of Infectious Diseases and Clinical Microbiology, Istanbul, Turkey
}

\begin{abstract}
Hepatitis B virus (HBV) is still one of the major reasons of the liver disease and it increases the risk of the development of chronic hepatitis, cirrhosis and hepatocellular carcinoma as late-term complications. HBV is partially double-stranded DNA virus that is a member of the Hepadnaviridae virus family. HBV genome contains a small $(3.2 \mathrm{~kb})$ covalently closed circular DNA (cccDNA) that is transcribed to generate four known transcripts $(3.5 \mathrm{~kb}, 2.4 \mathrm{~kb}, 2.1$ $\mathrm{kb}$ and $0.7 \mathrm{~kb}$ size). These transcripts are encoded to produce polymerase, $\mathrm{HBcAg}, \mathrm{HBeAg}, \mathrm{HBsAg}$ (L, M, S surface proteins) and $\mathrm{HBx}$ that have defined roles in HBV life cycle and liver injury. Currently, available treatments for chronic hepatitis B are interferon (IFN) monotherapies (conventional IFN- $\alpha$ and Peg-IFN- $\alpha$ ) or nucleos(t)ide analogues (lamivudine, adefovir, telbivudine, entecavir and tenofovir). None of currently approved drugs are curative for HBV infection since they rarely achieve virus eradication. New anti-HBV agents targeting different molecules involved in HBV infection and replication are needed to achieve curative treatments. To understand the HBV biology and life-cycle in detail is of critical importance for developing new anti-HBV agents to identify possible future targets for drugs. The aim of this review was to highlight the HBV replication and life cycle.
\end{abstract}

Key Words: Biology, HBV, hepatitis B virus, life-cycle, replication

Conflict of interest: The authors reported no conflict of interest related to this article.

\section{ÖZET}

Hepatit B virüsü (HBV) hala karaciğer hastalığının başlıca nedenlerinden biridir ve uzun dönemde görülen komplikasyonlar olan kronik hepatit, siroz ve hepatosellüler karsinomanın gelişme riskini arttıır. HBV kısmi çift-sarmallı Hepadnaviridae ailesine ait bir virüstür. HBV genomu bilinen 4 farklı transkripti oluşturan 3.2 kb'lık süpersarmal yapısında kovalent bağlı kapalı sirküler DNA (cccDNA)'yı içerir. Bu transkriptler HBV yaşam siklusunda ve karaciğer hasarında belirli rol oynayan polimeraz, HBcAg, HBeAg, HBsAg (L, M ve $S$ yüzey proteinleri) ve $\mathrm{HBx}$ proteinlerini sentezletirler. Günümüzde kronik hepatit B tedavisi için interferon tedavisi (klasik IFN - $\alpha$ ve PegIFN- $\alpha$ ) veya nükleoz(t)id analogları (lamivudin, adefovir, telbivudin, entekavir ve tenofovir) kullanılmaktadır. Bu onaylı ilaçların hiçbirisi, nadiren virusun eradikasyonuna yol açtıklarından, HBV enfeksiyonu için küratif değildirler. HBV enfeksiyonu ve replikasyonunda yer alan farklı molekülleri hedefleyen yeni anti-viral ajanlara ihtiyaç vardır. Gelecek ilaç hedeflerinin belirlenmesi, yeni sınıf anti-viral ilaçların geliştirilmesi için HBV biyolojisi ve yaşam siklusunu anlamak kritik önem taşımaktadır. Bu derlemede amaç HBV replikasyonu ve yaşam siklusunu vurgulamaktır.

Anahtar Kelimeler: Biyoloji, HBV, hepatit B virüsü, yaşam-siklusu, replikasyon

Çıkar çatışması: Yazarlar bu makale ile ilgili olarak herhangi bir çıkar çatışması bildirmemişlerdir.

\section{Introduction}

After Nobel Prize winner Blumberg discovered a new antigen called Australia antigen (AuAg) in serum samples of Australian Aborigines in 1963, AuAg became the first specific marker for viral hepatitis. Viral hepatitis B became a driving force for the development of modern virus diagnostics and vaccines in the following years (1). Hepatitis B virus (HBV) is a major reason of the liver disease and it can lead to acute and chronic inflammation of the liver (2). HBV can cause late-term complications like chronic hepatitis, cirrhosis and hepatocellular carcinoma; therefore, it is still one of the important global health problems (3). It is estimated that 
Inan et al.

Hepatitis B Virus: Biology and Life Cycle

there are still 240 million chronic HBV carriers worldwide and more than 620.000 deaths occur each year due to its complications, such as cirrhosis or hepatocellular carcinoma (1). Approximately half of the world's population lives in HBV endemic areas and hepatitis B surface antigen (HBsAg) seroprevalence is more than $8 \%$ (4). Although, the prevalence of HBV infection varies across the various regions of the Turkey (3.5-6.8\%), which is located in the intermediate endemic area with a $4 \%$ overall HBsAg seropositivity rate (5).

Nowadays, conventional interferon- $\alpha$ (IFN), pegylated interferon- $\alpha$ (Peg-IFN) and nucleos(t)ide analogs are approved agents for the treatment of chronic hepatitis B. While IFN has an anti-viral, anti-proliferative and immunomodulator effects, nucleoside analogs (lamivudine, entecavir, telbivudine) and nucleotide analogs (adefovir, tenofovir) inhibit DNA polymerase of the HBV and cause chain termination (6). Although, they suppress HBV replication, reduce liver inflammation and induce remission of the liver disease, none of currently approved drugs are curative for HBV infection since they rarely achieve virus eradication $(6,7)$. New anti-HBV agents targeting different molecules involved in HBV infection and replication are needed to achieve curative treatments (8).

It is essentially important to understand the HBV biology and life-cycle in detail for developing new classes of anti-HBV agents to identify possible future drug targets. Genotypes of HBV.

HBV belongs to Hepadnaviridae family and with its exceptional features, similar to retroviruses; it replicates through an RNA intermediate and can integrate into the host genome. In this way, these unique features of the HBV replication cycle maintains persistence of HBV infection in hepatocytes (9). There are 10 different genotypes of HBV (A-J), which are based on more than $8 \%$ genetic diversity and these are further divided into subgenotypes if genomic diversity is between $4 \%$ and $8 \%$. HBV genotypes and subgenotypes have specific geographical distribution patterns (10). It has been shown that natural course of HBV infection, HCC development, HBeAg seroconversion, prognosis and clinical outcomes of the liver diseases as well as the response to the antiviral treatment differ according to virus genotypes and subgenotypes $(10,11)$. It has been reported that there was a relationship of genotypes with core-promoter and basal-core-promoter mutations (12). There were very important pathogenic differences between HBV genotypes, for example; an acute infection with genotypes $A$ and $D$ more frequently progressed to chronic infection than other genotypes. It has been detected that chronic infection with genotypes $C$ and $D$ had higher progression rates to advanced liver disease and HCC than genotypes A and B. Nevertheless, genotypes $\mathrm{C}$ and $\mathrm{D}$ had lower response rates to IFN-based therapy than genotypes $A$ and $B$ (12). Unfortunately, genotype $D$ is predominant genotype in patients with chronic hepatitis B in Turkey (13).

\section{HBV Structure}

Dane particle $(42 \mathrm{~nm})$, spherical $(20 \mathrm{~nm})$ and filamentous (22 $\mathrm{nm})$ particles are three different viral structures that were observed in serum of HBV-infected patients by electron microscopy (9). All the three particles have a common HBsAg on their surface (14). The spherical and filamentous particles are composed of HBsAg and host-derived lipids without HBV genome; thus, they are non-infectious $(9,14)$. On the other hand, Dane particle is a $42 \mathrm{~nm}$ sphere which is complete infectious HBV virion. The core region of Dane particle contains a small, circular, partially double-stranded DNA molecule and viral DNA polymerase that surrounded by nucleocapsid. Assembled hepatitis B core antigens ( $\mathrm{HBcAg}$ ) build nucleocapsid that is covered with a lipid envelope containing HBsAg (9). The cholesterol-rich composition of the lipid envelope is required for viral infectivity (15). During budding of the nucleocapsid from the endoplasmic reticulum, the nucleocapsid induces ordered and condensed arrangement of the three different surface glycoproteins: $L$ (large), $M$ (middle) and $S$ (small) on the envelope membrane $(15,16)$ (Figure 1). Persistence of the S HBsAg in the serum over a period of more than 6 months is usually accepted as chronic infection and most commercial assays were designed to detect S HBsAg (16).

\section{HBV Genome Organisation}

The nucleocapsid structure of HBV contains HBV genome with is 3.2 kilobase $(\mathrm{kb})$ in length and partially double-stranded relaxed circular DNA (rcDNA) molecule $(15,16)$. Nucleocapsid is formed by composition of 240 viral capsid proteins with $27 \mathrm{~nm}$ diameter in an icosahedral structure, and it contains single copy of viral genome DNA and viral polymerase enzyme covalently attached to $5^{\prime}$ end of the negative chain $(9,16)$. Some cellular proteins including protein kinases are also packed in nucleocapsid structure (16). One of unique characteristics of HBV genome is asymmetric structure of the two chains. Although negative chain has the genome length, complementary positive chain may be at different lengths (14).

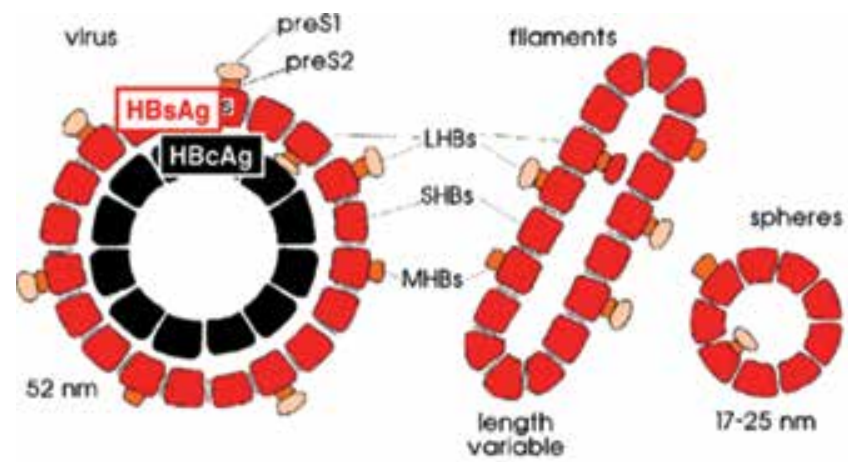

Figure 1. HBV (Dane particle) and the filamentous or spherical HBsAg particles. Although Dane particle size is defined as $42 \mathrm{~nm}$, hydrodynamic diameter of Dane particle is $52 \mathrm{~nm}$ including the outer preS1 and preS2 domains (1)
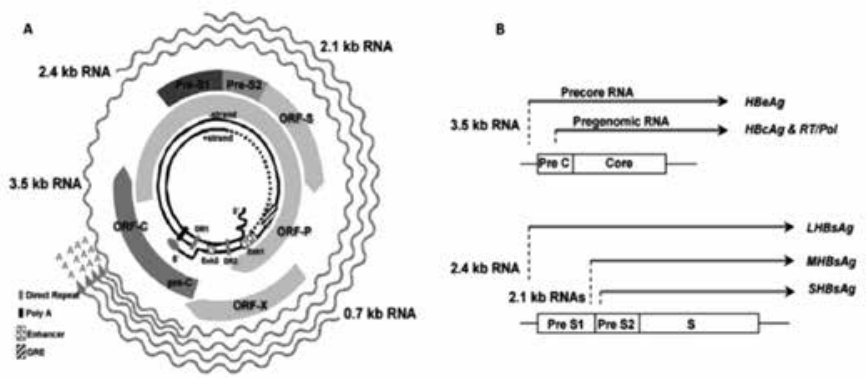

Figure 2. A. Organization of HBV genome and key regulatory elements B. Transcripts and their related proteins of HBV (9) 
Viral genome contains overlapping and open reading frames (ORF) for S, C, P, and X coding for four different proteins (9). Overlapping structure of coding regions facilitates the use of $\mathrm{HBV}$ genome with 150\% efficiency (10) (Figure 2).

The summary of 4 ORF regions and proteins coded are given below:

- PreS1/PreS2 and S gene (codes for 3 envelope proteins namely $\mathrm{L}-, \mathrm{M}-$, and $\mathrm{S}$ )

- Precore/core gene (codes for nucleocapsid protein; $\mathrm{HBcAg}$ and non-structurally secreted protein; $\mathrm{HBeAg}$ )

- Polymerase gene (Reverse transcriptase, RNAase $\mathrm{H}$ and terminal protein domains)

- $X$ gene (codes for small regulatory $X$ protein)

Although $S$ and $C$ genes have a single ORF, they may synthesize functionally different gene products, because they have different start codons $(9,14)$. S and C ORFs extend to preS (preS1 and preS2) and preC regions at $5^{\prime}$ end, respectively. In overlapping regions, there are regulators which are 4 promoters (preC/C, preS1/S and X) and 2 enhancers, and they allow expression of 7 different proteins transcribed at different codons by at least 5 different mRNAs with unattached ends (17). Two repeating regions with 11 bps, called as direct repeat 1 (DR1) and DR2, are located at $5^{\prime}$ ends of negative and positive chains, and they play a critical role in viral DNA replication. They are required for chain specific DNA synthesis $(9,18)$. Two enhancers, indicated as Enh1 and Enh2, provide liver-specific expressions of viral gene products (9). mRNAs are defined according to their lengths as $3.5 \mathrm{kbs}$ (long precore-core and pregenomic mRNA), $2.4 \mathrm{kbs}$ ( $L$ surface mRNA), $2.1 \mathrm{~kb}$ (M and $S$ surface mRNAs), $0.7 \mathrm{kbs}$ (X mRNA) (14).

S ORF region, which codes for viral surface proteins (HBsAg) is divided structurally and functionally into preS1, preS2, and $S$ regions with 3 different AUG start codons (2). While L HBsAg, which has the main role in receptor binding, is synthesized as the result of preS1mRNA translation containing preS1, preS2, and $\mathrm{S}$ domains; $\mathrm{M}$ and $\mathrm{S} H \mathrm{HBAg}$ proteins are synthesized as the results of preS2/S mRNA and S mRNA translations $(14,17,18,19)$.

$\mathrm{HBsAg}$ is the glycolised envelope protein of HBV virion. Like $\mathrm{HBsAg}$ presence on mature virions, HBV carriers contain excessive amount of non-infectious spherical and tubular particular HBsAg in their serum. These subviral particles are secreted excessively (100-100.000 folds) when compared with the mature virions (19). It has been reported that the reason of spherical and tubular particle synthesis, which are thousands folds more than Dane particles, might be a trap for the immune system, so that, chronic infection would develop $(1,14)$.

HBsAg is also synthesized from viral sequences coincidentally integrated in host cell genome. Amount of HBV DNA not only indicates viral replication, but also provides complementary information different from HBV DNA level. HBsAg is not only produced by translation of mRNA of cccDNA, but also from integrated DNA. This condition may help us understand infectious state of the patient more comprehensively (19).

$S, M$, and $L$ envelope proteins are different transmembrane keys sharing the same $\mathrm{C}$-terminal domain, but different $\mathrm{N}$-terminal domains which are pertinent for S protein (20). HBV envelope proteins are integral membrane proteins, which anchor cellular membrane by $\mathrm{S}$ domain, which exists in all 3 surface proteins, and is located in Asn-146 N-glycosylation region. In preS2 domain, there is Asn-4 glycosylation region that is used in M HBs, but not in L HBs (2). $\mathrm{S}$ region codes for $\mathrm{S}$ protein, which is critical for virus binding and infectivity. Myristic acid is bound to glycine in preS1 $\mathrm{N}$ terminal end of $L$ protein (18) (Figure 3).

$\mathrm{C}$ ORF region has precore and core regions coding for $\mathrm{HBCAg}$ (structural core protein of nucleocapsid) and $\mathrm{HBeAg}$ (soluble nucleocapsid protein) according to starting of translation in precore or core regions. Core protein has an intrinsic characteristic of self-binding, and forming a capsid-like structure, and C-terminal with RNA-binding activity is rich in arginine, and also has quite basic aminoacid clusters $(9,18)$. While precore ORF cods for precore-core protein causing $\mathrm{HBeAg}$ secretion by posttranslational modification, it also causes secretion of pregenomic mRNA, core, and polymerase $(14,18)$. Although it is unnecessary for viral replication, HBeAg may act as immune tolerant for development of persistent infection. If $\mathrm{HBeAg}$ level is decreased in natural progress by itself or during treatment, it may be a sign of switching from a high replicative state to low replicative phase (14).

PORF region codes for polymerase which is a large protein, and is divided into four functional domains (9). At the same time, pregenomic mRNA acts as a mold for progeny viral DNA genome synthesized for virus replication by reverse transcriptase. HBV polymerase is a multifunctional enzyme acting in encapsidation, at initiation of negative-DNA chain synthesis, in reverse transcription, and pregenomic RNA destruction. HBV polymerase protein is constituted from terminal protein domain (responsible for initiation of replication), spacer domain (its role is unknown), reverse transcriptase (RNA-dependent DNA polymerase) domain (it is responsible for viral RNA transcription and replication), and RNAase $\mathrm{H}$ domain (breaks pregenomic RNA) (18).

$X O R F$ region codes for $\mathrm{HBxAg}$ protein as the result of $\mathrm{X}$ mRNA translation. HBx protein has a role in HBV replication including signaling, transcriptional activation, DNA repair, and inhibition of protein degradation $(9,18)$. Additionally, it has been reported that HBXAg was required for in vivo productive HBV infection, as well as it contributes in oncogenic potential of HBV (9).

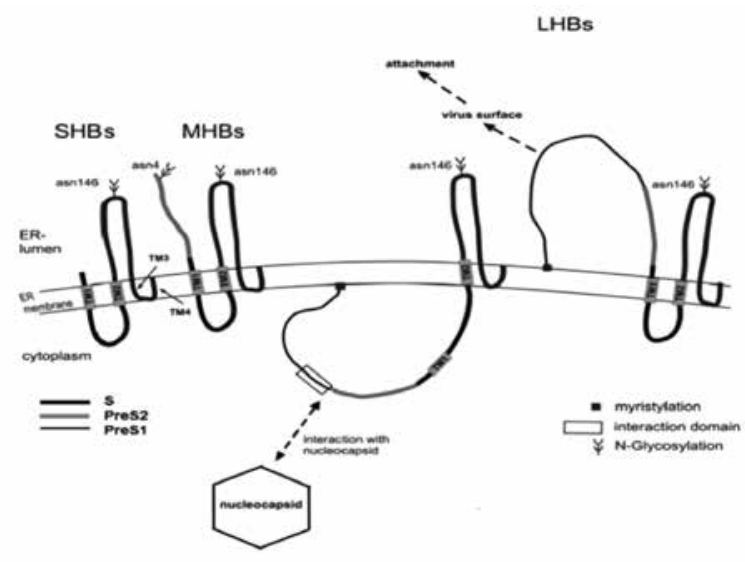

Figure 3. Schematic structure of the HBV surface proteins (modified from reference 2) 


\section{HBV Replication/HBV Life Cycle}

1- Reversible binding (attachment): Viral entrance plays an important role in hepatocellular tropism and species specificity, and it is the first step in interaction with the host. Viral entrance is the key target for host neutralizing antibodies for protective immune response and vaccine development (15). The first step in starting productive infection is initiated by low-affinity reversible binding between hepatocyte specific preS1 receptors on the outer membrane of mature Dane particle and heparan sulphate proteoglycans on hepatocytes $(8,14)$.

2- Irreversible binding with specific NTCP receptor: PreS1 domain of $L$ envelope protein is the key factor in receptor binding (20). This newly defined receptor called as NTCP (sodium taurocholate cotransporting polypeptide) is the entrance receptor (15). Yan et al. showed that NTCP, which had a role in bile salt transportation in the body, was mainly expressed in the liver, and multiple transmembrane transporter, as a functional HBV entrance receptor. HBV infection was inhibited in hepatic cells of humans and treeshrews (Tupaia belangeri chinensis) by silencing NTCP, non-susceptible hepatocarcinoma cells became HBV infectionsusceptible after exogenous expression of NTCP. They also could infect HepG2 cells, which were not susceptible to HBV infection, but used commonly in liver studies, by using NTCP obtained from humans and the treeshrews (20). NTCP is also known as SLC10A1 (Solute carrier family 10A1), which is the member of solid transporter family (SLC10). The SLC10 family has 7 members as SLC10A1-7 (8). NTCP is mainly located in the baseolateral hepatocyte membrane, and has a major role in streaming of conjugate bile salts form portal circulation into the liver (8). L-HBsAg of virus binds specifically and irreversibly to virus-specific preS1 receptor and this step requires the activation of the virus resulting in exposure of the myristoylated N-terminal of the L-protein (21). It is known that 2-48 aa region of preS1 of L-HBs protein has the major role in development of HBV infection $(8,20)$. It has been shown that anti-preS1 monoclonal antibodies might neutralize in vivo HBV infection by blocking binding of HBV to the cell (22). Similarly, it has also been shown that HBV infection may be prevented by synthetic peptides, such as anti-preS1 antibody Myrcludeks which may mimic this region $(8,23)$. Although the exact role of myristoylation is still not clear, it might increase receptor recognition by insertion of the acyl chain into membranes of the receptor complex (23). Recently, ferritin light chain (FTL) and squamous cell carcinoma antigen 1 (SCCA1) have been defined as co-receptors in HBV cellular binding and entrance into the hepatocytes (18).

3- Entrance (penetration): It has been proposed that entrance ways of viruses have different mechanisms both by endocytosis (3a) and fusion into plasma membrane of virus envelope (3b) (21). After binding to specific receptors, virion enters hepatocyte through host factors by endocytosis (18). It has been shown that Caveolin-, Clathrin- or macropinocytosis-mediated endocytosis may occur according to experimental system and used cell types during viral internalization $(8,18)$. Viral capsid enters the cytoplasm when viral envelope is fused to plasma membrane or endosome membrane after endocytosis $(16,21)$. Development of HBV infection is dependent on expression of host factors such as Rab5 and Rab7 (GTPases) acting in endosome biogenesis (18).
4- Viral nucleocapsid release: Viral nucleocapsid containing partial double-stranded rcDNA, which is covalently bound to polymerase, is released into the cytoplasm before it reaches to hepatocyte nucleus via HBV endocytosis (21) (Figure 4).

5- Nucleocapsid transportation: Transportation of capsid is facilitated by its interaction with cellular microtubules in the cytoplasm (16). Capsid carries its rcDNA to nucleus via nuclear pore complex (NPC) (18). This transportation occurs through relationship between nuclear localization signaling (NLS) in C-terminal of capsid protein and nuclear import receptors (importin- $\alpha$ and $\beta$ ) (18). Accumulation of nucleocapsid transported along microtubules on nuclear membrane increases interaction between NCP and adaptor proteins (21). Also, nuclear localization seems to be cellcycle dependent. It is believed that NLS exposure, which induces structural change in the capsid, is dependent on and regulated by the genome maturation (16).

6- Genome release: After nucleocapsid is trapped in NPC basket, disassemble of the capsid is completed, and rcDNA is released into the nucleoplasm $(16,21)$.

7- rcDNA repair: Viral polymerase completes positive chain of rcDNA. The polymerase present in $5^{\prime}$ end of the negative chain is used for positive chain synthesis. The short RNA-primer is used for the DNA positive strand synthesis. Both the polymerase and the short RNA-primer are removed through cellular enzymes of host such as proteinases (21). After positive chain is completed, it couples with the negative chain, and they are bound covalently at both ends forming circular supercoiled molecule (3).

8- cccDNA (covalently closed circular DNA) formation: Both DNA chains are covalently bound (DNA ligation). cccDNA molecule contains histone-and nonhistone-like proteins, and it is organized in a chromatin-like structure like beads lined up on a string. They are called as mini-chromosome serving as the template for the transcription of all the viral mRNAs $(14,21)$.

9- Transcription: cccDNA uses all cellular transcriptional mechanisms for protein production to perform all viral RNA synthesis, and viral replication. Transcription event is regulated by host transcription factors (CREB, STAT1, STAT2, etc.), chromatin modifying enzymes (PCAF, HDAC1, etc.), hepatocyte nuclear factors, and viral factors such as core, regulatory $X$ protein $(3,21)$. It regulates viral gene expression by interacting with viral promoters of main 4 ORF regions (21). It has been reported that transcription is regulated by epigenetic mechanisms such as DNA methylation of cccDNA, histone acetylation, etc. (3).

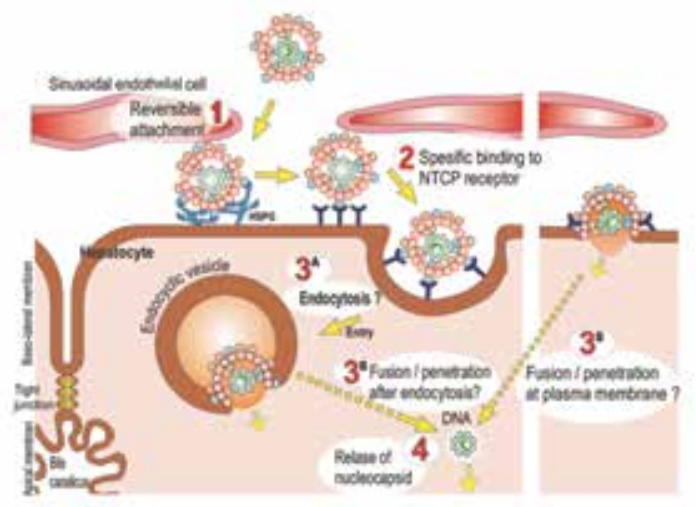

Figure 4. HBV enterence (modified from ref 21) 
10- Export of the nuclear RNA: All main 4 mRNAs use a common single polyadenylation signal. Stabilization, processing, and nuclear transportation of viral mRNAs occur through host factors (21). It has been shown that cellular type-related protein/nuclear export factor-1 (TAP/NFX1) and HBcAg play a role in transportation of HBV pregenomic RNA to the cytoplasm (18) (Figure 5).

11- Translation: While core protein and viral polymerase are synthesized as the result of progenomic RNA translation; regulatory $X$ proteins and $L, M$, and $S$ envelope proteins are formed by subgenomic RNA translation (18).

12- Assembly of nucleocapsid: $\mathrm{HBcAg}$ proteins forming nucleocapsid are preserved in different genotypes. HBcAg contains 183 or 185 aa according to the genotype, and it has two parts. According to the genotype, the first part contains an N-terminal with 149 aa or 151 aa, which is sufficient for self-binding of the capsid. The second part is known as C-terminal protamine domain with 34 aa, and it is rich in arginine, so it provides positive charge for the domain. Protamine domain is essential for packaging of pregenome/HBV pol complex (2). PgRNA is the template for the generation of new DNA genomes by reverse transcription (24). Replication requires encapsidation of pgRNA by core protein. This procedure is started by coordinated binding of secondary stem-loop structure, called as viral polymerase epsilon $(\varepsilon)$, and encapsidation is triggered for formation of viral nucleocapsid (14). HBV nucleocapsid formation starts as soon as pgRNA forms complexes with HBV polymerase and HBcAg dimers. Effective package of pgRNA requires phosphorylation of C-terminal of the core protein. While mature DNA containing nucleocapsid is formed from nucleocapsid containing immature RNA, dephosphorylation and conformational changes occur (2).

13- Reverse transcriptase: As HBV polymerase binds to epsilon region of pgRNA, it acts as protein primer for the synthesis of polymerase negative DNA chain. As pgRNA acts as a template for synthesis of negative DNA chain, the new chain elongates. After synthesis of negative DNA chain is completed, pgRNA template is broken down by $\mathrm{H}$ domain of polymerase ribonuclease (RNAse). Completed negative chain is used as template for positive chain synthesis. Positive chain synthesis is rarely completed, and it is found at different lengths in HBV virion. Maturation step is completed in the cytoplasm by switching of RNA to DNA inside the nucleocapsid. Although HBV replicates with RNA intermediary step, host genome integration is not required for HBV-DNA for

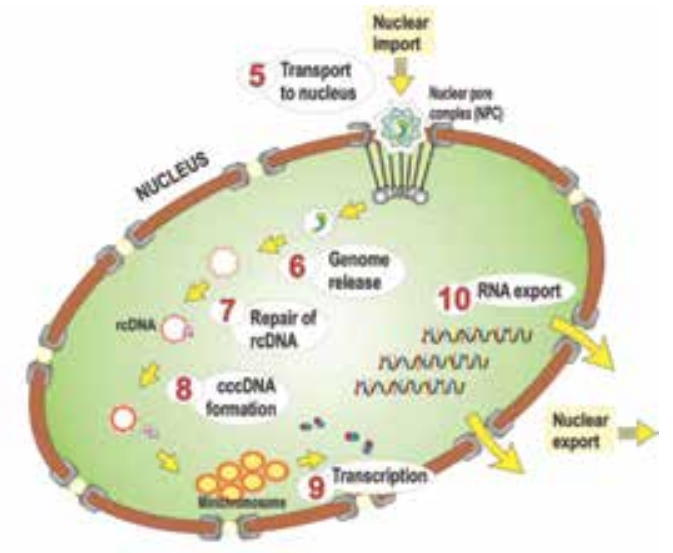

Figure 5. HBV in nucleus (modified from ref 21) viral replication $(2,14,21)$. However, integrated HBV-DNA to human genome is determined in all cases with HBV-related HCC (23).

14- Re-import of DNA containing mature nucleocapsid to nucleus to form additional cccDNA molecule (14A) or secretion after gaining its envelope (14B): Enveloping of mature nucleocapsid depends on the presence of viral surface proteins in the medium. Especially $L$ protein is required for nucleocapsid to gain its envelope. It has been shown that nucleocapsid is sent to nucleus so as to increase viral genome amplification if L-protein is absent (2). For example, as surface antigen level is low at the initial phase of infection, newly synthesized nucleocapsids are directly transported to the nucleus, and sustain cccDNA pool (17). It has been proposed that L-protein plays a role in negative feedback mechanism to suppress cccDNA amplification (21). Envelope proteins are added to endoplasmic reticulum membrane after translation, and they bud into the lumen of the endoplasmic reticulum. They are released as non-infectious subviral spherical and filamentous envelope particles or infectious Dane particles if they have gained envelope of DNA containing nucleocapsid by the cell (21). HBV budding and egress depend on functions of multivesicular body (MVB) pathway that have the unique ability to generate intraluminal vesicles. MVBs then fuse with the lysosome or the plasma membrane for intraluminal vesicles delivery. MVBs function depends on the endosomal sorting complex required for transport (ESCRT) system, Vps4 ATPase and associated proteins (25). During L-protein synthesis, preS1 domains are in contact with the cytoplasm, and they are myristoylated. At some steps, translocation may occur along the membrane after enveloping of the preS-mediated nucleocapsid $(11,21)$ (Figure 6).

15- cccDNA amplification: cccDNA, which is the circular, covalently bound form of viral chromosome, is required for the life cycle, and persistence of the infection. Many cellular functions of virus and host participate in synthesis of cccDNA from viral DNA (16). cccDNA is present in mini-chromosome form, and bound to histone proteins in the nucleus of the infected hepatocyte. Episomal DNA is persistent, and is not integrated into host cell genome $(14,17)$. Majority of cccDNA in hepatocyte nucleus originate from newly synthesized nucleocapsids. Although, cccDNA formation and the size of cccDNA pool are controlled by some viral end host factors that are not completely identified yet, it has been reported that immunological, virological, transcriptional, and epigenetic factors regulate cccDNA $(3,17,21)$. cccDNA, which is present as an intact episomal DNA that is not integrated into host DNA in infected hepatocyte nucleus, codes for 4 overlapping ORF regions, and it acts as template for all viral mRNA transcriptions in HBV replication $(14,18)$. Pregenomic RNA is also a derivative of cccDNA, and HBV-DNA is synthesized from pregenomic RNA via reverse transcriptase (18). It is observed that 1-50 cccDNA molecules are accumulated for one cell (21). Intranuclear cccDNA is regulated by the balance between the events such as intracellular transport, envelope formation, and release of nucleocapsid outside (17). The basic factor in treatment failure in chronic hepatitis with antivirals is that cccDNA is quite stable $(14,17)$. As cccDNA remains stable in the hepatocyte, it acts as the template for all viral mRNAs transcribed by cellular RNA polymerase-II, so it becomes a stable source for new virus generations $(14,23)$. Therefore, cccDNA has an important role in discontinuation of antiviral treatment, disease reactivation after immunosuppression, transplantation, and drug resistance (14). Yet, none of approved current treatments 
provide elimination of cccDNA existing within the nucleus of infected hepatocyte (11). If resistant mutants evolved by using oral nucleos(t)ide analogues, are archived in cccDNA, then multiple drug-resistant viruses may appear. Although, it is known that HBV is non-cytopathic itself, both cytosolic and non-cytosolic mechanisms are important in cccDNA elimination $(11,14)$. While in cytosolic mechanisms-infected hepatocytes are killed and switched with new, uninfected hepatocytes; in non-cytosolic mechanisms, antiviral cytokines down regulates the HBV gene expression, and HBV is eliminated from hepatocytes without cell death (14). Although HBV-polymerase inhibitors do not have direct effects on cccDNA, emerging of fewer nucleocapsids into the pool due to inhibition of viral DNA synthesis in the cytoplasm may explain the decrease in cccDNA level (21).

16- Secretion of DNA containing mature nucleocapsids and subviral particles: DNA-containing mature nucleocapsid is released from hepatocyte as infectious Dane particle after gaining lipid membrane with HbsAg proteins from the endoplasmic reticulum $(14,21)$. Non-infectious spherical and tubular subviral envelope particles are synthesized into blood 103-106 folds higher than in virion, and they do not contain nucleocapsid (14,21) (Figure 7).

Investigation of complex relationship between viral and host cellular structures is the most interested topic of HBV biology, and it has additional key points in developing more effective and new treatment modalities for chronic hepatitis B (24).

HBV use reverse transcriptase, which does not have proofreading function, during synthesis of its DNA copy. Therefore, it is naturally prone for errors, which may end up with evolving of rapidly mutant genes. Endogenous causes such as immune clearance of the host, and exogenous causes such as vaccination, HBlg, and antiviral drugs may lead to appearance of escape mutants by causing selection pressure on rapidly replicating viruses with the rate of 1011 virion/day. Heterogeneous mixture of HBV population in the host cells is called as "quasi-species" (26). HBV mutation results in endangered both treatment and vaccination success rates. Each step of HBV replication is still being molecularly investigated to define new treatment targets, because of persistent problems such as resistance in treatments with nucleotide analogues, determining mutant viruses which escape from vaccination, high side effects rate in interferon-based treatments, and low treatment response rates, etc.

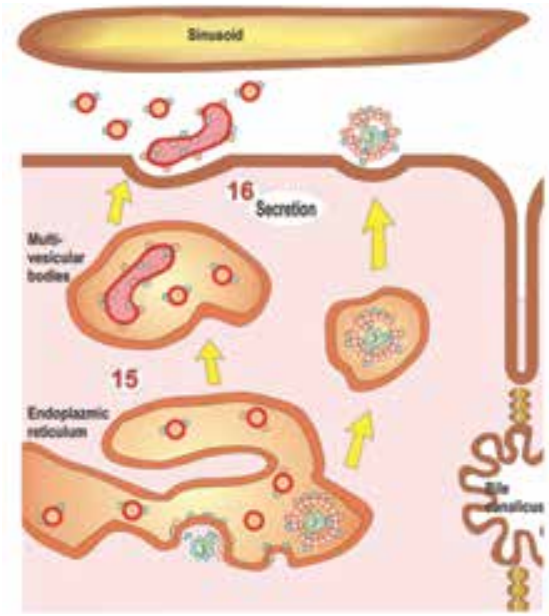

Figure 7. Secretion of HBV virions (modified from ref 21)
Interactions between HBV and host cellular structures at all steps of replication including especially maturation, binding, and budding have been investigated (25). Although our knowledge about host cellular factors and their engagements in HBV replication, whose vaccine we have had for the last 30 years, is still increasing; it is clear that we are far behind complete understanding of HBV replication and the cell biology. Better understanding of each step of replication starting at entrance of HBV into hepatocyte to release, will not only fascinate the interested individuals, but also will provide priceless information to define future anti-viral treatment strategies, new diagnostic and predictive indicators.

\section{Acknowledgement}

Many thanks to Dr. Süreyya Altunay for redrawing of figures (4-7).

\section{References}

1. Gerlich WH. Medical virology of hepatitis B: how it began and where we are now. Virol J. 2013; 10: 239.

2. Schadlar S, Hildt E. HBV life cycle: entry and morphogenesis. Viruses. 2009; 1:185-209.

3. Zhang $X$, Hou J, Lu M. Regulation of hepatitis B virus replication by epigenetic mechanisms and microRNAs. Front Genet. 2013; 14:202.

4. Robinson BJ, Pierson SLL. Clinical Virology. In: Mahon CR Lehman DC, Manuselis G (eds.), Textbook of Diagnostic Microbiology. 4th ed. China: Saunders; 2011. p.732.

5. Ay P, Torunoglu MA, Com S, Çipil Z, Mollahaliloğlu S, Erkoc Y, Dilman U. Trends of hepatitis B notification rates in Turkey, 1990 to 2012. Euro Surveill. 2013; 18 pii:20636.

6. Uhl P, Fricker G, Haberkorn U, Mier W. Current status in the therapy of liver diseases. Int J Mol Sci. 2014; 15:7500-7512.

7. Bertoletti A. Gehring AJ. Immune therapeutic strategies in chronic hepatitis B virus infection: virus or inflamation control? PloS Pathog. 2013; 9: e1003784.

8. Watashi K, Urban S, Li W, Wakita T. NTCP and beyond: opening the door to unveil hepatitis B virus entry. Int J Mol Sci. 2014; 15:2892-2905.

9. Liang TJ. Hepatitis B: the virus and disease. Hepatology. 2009; 49(Suppl 5):13-21.

10. Zhang Q, Cao G. Genotypes, mutations, and viral load of hepatitis $B$ virus and the risk of hepatocellular carcinoma: HBV properties and hepatocarcinogenesis. Hepat Mon. 2011; 11:86-91.

11. Grimm D, Thimme R, Blum HE. HBV life cycle and novel drug targets. Hepatol Int. 2011; 5:644-653.

12. Tanwar S, Dusheiko G. Is there any value to hepatitis B virus genotype analysis? Curr Gastroenterol Rep. 2012; 14:37-46.

13. Sunbul M, Leblebicioglu $H$. Distribution of hepatitis $B$ virus genotypes in patients with chronic hepatitis B in Turkey. World J Gastroenterol. 2005; 11:1976-1980.

14. Doo EC, Ghany MG. Hepatitis B virology for clinicians. Clin Liver Dis. 2010; 14: 397-408.

15. Baumert TF, Meredith L, Ni Y, Felmlee DJ, McKeating JA, Urban S. Entry of hepatitis $B$ and $C$ viruses-recent progress and future impact. Curr Opin Virol. 2014; 4: 58-65.

16. Block TM, Guo H, Guo JT. Molecular virology hepatitis B virus for clinicians. Clin Liver Dis. 2007; 11:685-706.

17. Kann M. Structural and Molecular Virology. In: Lai CL, Locarnini S(eds), Hepatitis B Virus. 2nd ed. London: International Medical Press; 2008. P2-2. 
18. Ezzikouri S, Ozawa M, Kohara M, Elmdaghri N, Benjelloun S, Tsukiyama-Kohara K. Recent insights into hepatitis B virushost interactions. J Med Virol. 2014; 86:925-932.

19.Tseng TC, Kao JH. Clinical utility of quantitative HBsAg in natural history and nucleos(t)ide analogue treatment of chronic hepatitis B: new trick of old dog. J Gastroenterol. 2013; 48:13-21.

20. Yan $H$, Zhong G, Xu G, He W, Jing Z, Gao Z, Huang $Y$, Qi $Y$, Peng $B$, Wang $H$, Fu L, Song $M$, Chen P, Gao W, Ren B, Sun $Y$, Cai T, Feng $X$, Sui J, Li W. Sodium taurocholate cotransporting polypeptide is a functional receptor for human hepatitis $B$ and D virus. Elife. 2012; 1: e00049.

21. Urban S, Schulze A, Dandri M, Peterson J. The replication cycle of hepatitis B virus. J Hepatol. 2010; 52:282-284.
22. Hong HJ, Ryu CJ, Hur H, Kim S, Oh HK, Oh MS, Park SY. In vivo neutralization of hepatitis $B$ virus infection by an anti-preS1 humanized antibody in chimpanzees. Virology. 2004; 318:134141.

23. Glebe D. Recent advances in hepatitis B virus research: A German point of view. World J Gastroenterol. 2007; 13:8-13.

24. Beck J, Nassal M. Hepatitis B virus infection. World J Gastroenterol. 2007; 13:48-64.

25. Prange R. Host factors involved in hepatitis virus maturation, assembly, and egress. Med Microbiol Immunol. 2012; 201:449-461.

26. Locarnini S. Molecular virology of hepatitis B virus. Semin Liver Dis. 2004; 24(Suppl 1):3-10. 